\title{
FIRST AS TRAGEDY, THEN AS TELEVISION SERIES: TEACHING THE PRESENTATION OF HISTORY IN A FRENCH VILLAGE
}

Donald Reid

University of North Carolina

Americans and Europeans increasingly look to the television drama series for their historical education, whether about Chernobyl or the struggle to pass the Equal Rights Amendment. ${ }^{1}$ We have long shown documentaries to students and fact-checked docudramas and dramatic films set in the past, but the television drama series offers new opportunities and challenges. The extended viewing time and the sustained involvement the audience has with a television drama series distinguishes it from documentaries, docudramas, and dramatic films. While there is an extensive literature on the presentation of history in film, much less scholarly analysis exists on the television drama series and how it communicates ideas about the past. ${ }^{2}$ The feuilleton quality of episodes and hiatus between them (unless binge-watched on a streaming service) leaves viewers to think through the narrative of the series itself as they wait for the next episode. Edgar Reitz's Heimat: A Chronicle (1984) presented continuity and change in a twentieth-century German village over several generations, but Frédéric Krivine and his team's A French Village (2009-2017) has a different ambition: to permit viewers to interpret a particular historical event-the German occupation of France during World War II-in ways they had not before. Can a television series present the complexities of this history and the issues it raises? Can it convey these debates to a large audience? What impact does this form of presentation have on viewers' understanding of the past? A diverse group of first-year students addresses these questions in a seminar I teach on A French Village. ${ }^{3}$ Students learn about the occupation of France during the Second World War, and they study postwar debates about its history and memory. However, the primary goal of the course is to develop students' abilities to analyze the presentation of history outside of books or documentary films by examining a work in a genre that most of them engage with more often and perhaps more deeply, the television drama series. Students ask when imagination could (or could not) enable an audience to see what happened in the past in revealing new ways.

\section{Controversy and Context: The Development of A French Village}

In 2006, Jonathan Littel published The Kindly Ones, a novel that explored the mind of an SS officer. Claude Lanzmann, the director of Shoah (1985), thought that those born after the war like Littel should not make its horrors the subject of fiction. The resister, novelist, and scriptwriter Jorge Semprun disagreed. He praised Littel's novel and thought that the creative efforts of later generations were necessary to keep the French interested in the wartime experience and the issues it raised. ${ }^{4}$ The team that produced A French Village made a nod to Littel in their presentation of the SS officer Heinrich Müller, a character as complex as he is cruel. ${ }^{5}$ Krivine introduced in France the creative practices of American shows like The Wire and Breaking Bad to make a series set in Villeneuve, a fictional town in the Jura situated on the line that initially divided defeated France between the

\footnotetext{
${ }^{1}$ Johan Renck, Chernobyl (2019); Davhi Waller, Mrs. America (2020).

${ }^{2}$ On the presentation of history in movies, see Robert Rosenstone, History on Film/Film on History, 3rd edition (New York: Routledge, 2017). There are many studies of the historical past in individual films. For the period under consideration, a good guide is Leah D. Hewitt, Remembering the Occupation in French Film: National Identity in Postwar Europe (New York: Palgrave Macmillan, 2008).

${ }^{3}$ A French Village is available on Amazon and other streaming sites. I would like to take this opportunity to thank my students, my collaborators and resisters in this project.

4 “Lanzmann juge Les Bienveillantes," Le Nouvel Observateur, September 21, 2006, 27; Jorge Semprun, "Le Big Bang Littell," L'Express, November 9, 2006, 126.

${ }^{5}$ The historical figure Heinrich Müller was the SS officer in charge of the Gestapo. The SS officer Heinrich Müller in A French Village shares his name, but not his biography. The series gives its Heinrich Müller a life after the war, whereas the historical Heinrich Müller disappeared at the war's end, leaving only a string of hypotheses and unverifiable sightings.
}

(C) 2021 Reid. Free to copy and share for education and scholarship under a Creative Commons Attribution NonCommercial-NoDerivatives 4.0 License. 
region governed by the Vichy regime and that under direct German control. In 72 episodes of 45-50 minutes, broadcast over nine years, a large, faithful viewing audience in France followed the lives of inhabitants of Villeneuve and their relations with the German army and the Gestapo stationed in the city, and later with the American army, from 1940 to 1945 . A final season examines the afterlives of characters in light of their wartime experiences. ${ }^{6}$

A French Village devotes particular attention to what Jean-Pierre Azéma, a leading historian of the occupation and adviser to the series, refers to as the "gray zone" constituted by the French making decisions about identity and survival throughout the war. ${ }^{7}$ Students find this concept particularly helpful and introduce it into their analyses of subjects not explicitly addressed in these terms by Azéma. After the war, the French, broadly speaking, saw themselves as having been a "people in resistance" during the occupation. However, in the 1970s, the first postwar generation came to see occupied France as a nation of collaborators, deeply complicit in the deportation of Jews. While historians have developed more nuanced understandings of the lived experience of the French in occupied France, the French as a whole have clung to a categorization of the population as collaborators, resisters, and fence sitters. ${ }^{8}$ In A French Village, the showrunners present the often troubling ambiguities of people living in difficult times, who may not have fallen into solely one of these groups, and to the extent that they did, it may not have been for the reasons given by postwar generations. The series has been well received by historians of occupied France..$^{9}$ Viewing, discussing, and writing about A French Village with these issues in mind develops students' abilities as historians and as analysts of the possibilities and limitations of presentation of the past in a genre whose complexities they both know and do not know well.

\section{Teaching A French Village: The Purpose and Context of the Course}

My course on A French Village is a seminar with twenty-four first-year students. I have offered it a couple of times and will continue to do so. It is a general elective, and few students in the class plan to be history majors. Most are embarked on studies in business, medicine, and computer science. At the beginning of the class, their knowledge of the history of twentieth-century France, like the knowledge of history that most viewers bring to historical drama, is sketchy.

Over the course of the semester, I give more than a dozen short lectures on the political history of the period and topics addressed in the series like the school system, the children born to German-French couples, the prosecution of rape cases by the American army, and the Vichy Syndrome to provide the students with context and to introduce them to recent historical work on the occupation and on the collective memory of the period. Students read selections from primary documents by Marc Bloch, Marshall Pétain, and Jean-Paul Sartre, among others, and from secondary works by Julian Jackson, Chris Millington, Robert Paxton, Henry Rousso, and Olivier Wieviorka to give them the grounding to assess the choices made by Krivine and his team in A French Village. In addition, students discuss selections from two documentaries: Marcel Ophuls' The Sorrow and the Pity (1969) and Claude Chabrol's The Eye of Vichy (1993), whose script was written by Azéma and Paxton. Students realize they are looking for a different sense of "truth" in documentary and dramatic films, although the genres borrow techniques from one another. They also view and discuss the postwar Resistance epic by René Clément, The Battle of the Rails (1946) and Louis Malle's Lacombe Lucien (1974), whose iconoclastic treatment of the occupation clearly influenced A French Village.

\footnotetext{
${ }^{6}$ When broadcast, the audience averaged close to 3.5 million viewers; many later watched the series on DVD or by streaming. Barnard Papin, Un Village français. L'Histoire au risque de la fiction (Neuilly: Atlande, 2017), 142.

${ }^{7}$ In 1986, the Holocaust survivor Primo Levi introduced the term "the gray zone" for prisoners who collaborated in one way or another with the camp authorities. Primo Levi, The Drowned and the Saved, trans. Raymond Rosenthal (New York: Vintage, 1989), 36-69.

${ }^{8}$ Pierre Laborie, Le chagrin et le venin. La France sous l'Occupation, mémoire et idées reçues (Montrouge: Bayard, 2011).

${ }^{9}$ For the history and reception of the series in France, see Donald Reid, "Un Village français: Imagining Lives in Occupied France," French Cultural Studies 30, no. 3 (August 2019): 220-231.
} 
Fifteen-minute lectures and short readings assure that students have the time to view the series carefully and to discuss it thoroughly in class. Five-to-ten minute bonus files composed of a brief presentation by Azéma and extracts from oral histories relating to the subject he discusses accompany the series. Viewing these is not a substitute for lectures and readings on the period. However, discussing what they see in the oral histories in light of contemporary historical scholarship and of the presentation of the occupation in the series allows students to analyze sources. These oral histories, generally focused on individuals' families, accentuate the positive, in the form of acts that led to survival. While A French Village examines the collaboration of mayors with the German occupiers, a number of the oral histories discuss mayors' acts of resistance, like the provision of fake IDs and ration cards, subjects absent from the series.

Scriptwriters are a particular kind of storytellers, and the series is a medium that encourages the telling of several stories at once or one story in several ways. Events in A French Village have a basis in the historical record, but the ways they are put together in a single community presents challenges the students explore. We address important elements of screenwriting like synchronicity, and we examine the presentation of a common theme in a diversity of situations in one episode to lead the viewer to recognize unexpected relationships or parallel situations that have different consequences. Nowhere is this more evident than in the love lives of characters. As a rule of thumb, heterosexual marriage between individuals of the same nationality and religion lack amour, whereas homosexual liaisons and illicit heterosexual relationships between French citizens and those who are not, and between Jews and non-Jews, are more romantic as well as sites where the personal is necessarily the political. A French Village is a soap opera, and some of the best discussions come when students ask themselves whether this kept them more engaged with the series at the expense of understanding the historical situation, or whether this, in fact, leads them to understand better and more fully the stresses and demands placed on the French during the occupation. The goal is not for students to repress their emotional responses, but for them to see that involvement as an element of the success of the series and to analyze the particular historical interpretations that this encourages and discourages. It is also important that students explore the possibilities that different choices in filming allow. Close study of individual scenes, with discussion led by students, is particularly rewarding. Given a vocabulary to express their ideas, students are good at this task. ${ }^{10}$ They are, for instance, particularly aware of how the community of Villeneuve confronts the unknown when introduced to desperate groups from the exterior, like the Spanish Civil War refugees seeking shelter in the church or the trainload of Jews housed in the school. Camera angle and the shared perspective-of the viewer and Villeneuve residents at some points and the outsiders looking at the inhabitants of Villeneuve community at other timesinvolves viewers emotionally in the chaos and inhumanity that characterized these historical situations.

Historians are trained to support arguments with evidence, but not to present seemingly extraneous details like those that make individuals human, a necessity in a television drama series. I encourage students to think of themselves in the role of showrunners. How can they construct a narrative that conveys understandings of history without seeming to do so, and that audiences which do not watch the show with the intention of learning about the past, will embrace? In a limited amount of screen time, what are the goals in terms of history and story and of emotional impact, and how well are they realized? To address these questions and engage students in considering them, I organize some classes as working groups called to review episodes in which selected students act as writers and as directors. To take one example, the series begins with the German invasion in 1940. Historians usually say such an event was traumatic and leave it at that, interested primarily in the long-term consequences of collective trauma. The first episodes of $A$ French Village immerse viewers in the confusion and the diversity of experiences that were repressed or erased when the invasion was compressed into a collective trauma. Some of the best working group presentations concern this issue in the final season of the series. Students come up with creative ways to deal with the dialectic of apparent absence and invisible omnipresence inherent

\footnotetext{
${ }^{10}$ A good place to start is "The Basics of How to Read a Film.” http://clevelandmediaclass.weebly.com/uploads/4/5/4/8/4548166/ opening_act film language.pdf
} 
in characters marked by traumatic memory of the occupation. Throughout the semester, students keep viewing notebooks that I review each week. Using what I learn from these, I put students in different break-out groups each week, composed of students I know are interested in a particular problem. I have the group formulate the issue as a thesis supported by evidence that they then present to the class as a whole for discussion. This helps students in turn think of historical texts and the television series not as collections of facts and scenes but as the basis of arguments constructed so as to make a point.

\section{Teaching A French Village: Students as Historians and as Showrunners}

The primary writing assignment for the semester is a research paper on a concept or subject in the series. Under my guidance, individual students familiarize themselves with historiographic debates on interpretation of the particular topic they choose. Students use this historiography as a starting point to examine the ways that the issue is addressed in the series. It is rare that as researchers, we are in a group in which all are deeply familiar with our major primary source. Having all viewed the series, students serve as knowledgeable critics and a receptive audience of one another's work.

By examining the findings of the students on subjects like collaboration, resistance, the Jewish experience, liberation, and the memory of the war, we can see how they become better and more daring practitioners of historical interpretation. They learn to treat the series as do research historians, who use documents for purposes other than those that apparently guided their creation. Students ask questions the showrunners had not intended to pose and take as evidence what the director and writers may not have understood they were telling viewers. In the show, don't tell manner of the series, viewers engage with the complex nature of collaboration in occupied France. In their papers, students develop typologies of the "gray zone" of collaboration. Daniel Larcher is called on to be mayor as the Germans arrive in Villeneuve. He is a sympathetic character who seeks to protect the population, but by the time he leaves office in 1942, the audience realizes that he had undertaken a fool's errand. If Daniel Larcher collaborates out of noblesse oblige, others do so with personal ambitions in mind. Raymond Schwartz and his wife Jeannine are business people who collaborate by doing business with the Germans, but later throw in their lot with the resistance. Raymond does so out of love for the resistance leader, Marie Germain, and Jeannine provides the resistance with funds and information as insurance should the Axis lose the war. Philippe Chassagne, Larcher's replacement as mayor, more easily fits the image of a collaborator. ${ }^{11}$ $\mathrm{He}$ is a social climber, as well as an ardent anti-Semite and anti-Communist who promotes more extreme policies than the Germans themselves. The French state collaborator is embodied by the sub-prefect Luc Servier, whose primary goal was not to protect the people or to forward an ideology, but to secure a role for the French state and for himself by doing the Germans' bidding. Viewers see as well that the bureaucracy that managed collaboration, represented by Vichy officials who sought to keep businesses taken from Jews in French hands, created significant opportunities for corruption.

Other students are attuned to the particular attention A French Village pays to policing. In a diversity of ways students pursue what they understand to be the Alltageschichte project of assessing how the everyday practices of the forces of order and responses to them could shape and alter, strengthen and weaken, police power. ${ }^{12}$ Students take this project in a number of directions, once again formulating and critiquing categorizations of a concept, in this case of policing. One student who worked on the police said that he liked some variant of "there are three forms of" in a lecture or text, but he had not realized all of the compromises and conflations that preceded such comforting affirmations until he did them himself (and analyzed how the scriptwriters had done them as well). The police commissioner Henri de Kervern, inherited by the Vichy regime from the Third Republic, believed that the French police should not take on the investigative work of the German occupiers:

\footnotetext{
${ }^{11}$ Historians would refer to Chassagne as a collaborationist because his fascist political views separate him from the collaborator out of necessity, Daniel Larcher.

${ }^{12}$ See Alf Lüdtke, ed., The History of Everyday Life: Reconstructing Historical Experiences and Ways of Life, trans. William Templer (Princeton: Princeton University Press, 1995).
} 
The job of the French police is such that they should appear to work hard, but make sure that they fail to find those who heckled Pétain and Hitler at the movie theatre. Jean Marchetti, who replaced de Kervern as head of the police in Villeneuve, has no such republican sensibility that would interfere with his duties to the new state. However, Marchetti is not an ideologue either. His authoritarian personality feeds on dominating people, but, in turn, like the SS officer Heinrich Müller, he is endowed with human foibles-Marchetti falls in love with a Jewish refugee, Rita de Witte, and has a child by her. That he does not personify the banality of evil makes him more accessible, but not more likeable.

The Milice was the paramilitary force established by the Vichy government in 1943 to combat the resistance. Viewers see that individual police agents could on occasion offer some limited protection to the resistance-a gendarme gives the resister Jules Bériot three hours to move a hidden printing press-and the police agent Vernet, talented at not coming up with Jews he is sent to round up, joins the Témoignage Chrétien resistance movement. As the tides of the war turned, the police as a whole show less enthusiasm for tracking down resisters. A Milice leader replaces Marchetti as police chief. In a melodramatic scene, the Milice make Vernet recite lines from Charles de Gaulle's moving speech of August 1944 in liberated Paris that the audience has already heard on a radio broadcast in the police station. The Milice then executes Vernet, his wife, and his young children.

The Milice are also the subject of what the students find to be the clearest example of the dramatic taking precedence over historical verisimilitude. As the American army approaches Villeneuve, the Milice and their families go to the station to catch a train to take them to shelter in Germany. Jews, including Rita de Witte, are there as well, awaiting a train to take them to their death. When the commanding German officer Schneider tells the Milice to shoot the Jews, the Milice leader refuses because the families of the Milice are present. As Schneider prepares to shoot the Jews himself, Marchetti shoots him-the second time he has killed a German soldier to defend Rita-and the Milice shoot the German troops who are with their officer. To make a Vichy police officer and the Milice responsible for a good portion of the deaths of German soldiers in the series is shocking and appears driven by the needs of the plot, not an effort to develop the audience's understanding of collaboration or the Milice. This incident is problematic, but students' exploration of such scenes in their papers and in discussion assures that they remain critics of what they were seeing, recognizing the uneasy relationship of history and drama.

As with collaboration, viewers see that entering the resistance, whether Gaullist, Communist, or that of the young men in the maquis who are escaping labor service in Germany, results from a confluence of personal, material, political, and ideological factors. The first resister the audience meets is a sex worker who gets information to relay to London from pillow talk with a German officer and passes it on to another client who is in the resistance. To enter the resistance, it is said that one had to know someone. With the exception of the Communist party, resisters did not work in organizations that had existed before the war. Resistance itself was a practice that resisters had to make up as they went along. If students are initially confused by resistance activities they see, they recognize that this is an instance when being unsure helps them to understand the past better. Discussion of the resistance gives students ample opportunity to assess the personal and social experience of life in the underground and to debate the moral and strategic decisions made by unprepared fighters. Although the resistance is credited with few accomplishments in the series, its presence, even if few resisters in the series join primarily out of loyalty to the nation and the republic, does temper the blanket condemnation of the French in occupied France as collaborators. The French were not the people in resistance that de Gaulle evoked, but there were people in resistance whose heterogeneity the series illustrates well. Students began the class with a dictionary definition of resistance, but as they recognize, resistance inhabits a "gray zone" of its own. Several students analyze acts of resistance not performed by a resister, like that of the schoolteacher Lucienne, or develop and defend in their papers and before the class typologies of resistance rooted in social histories of the lives of resisters.

The experience of Jews is a central question in debates over Vichy France. There would have been few Jews in a town in the Jura at the outbreak of the war. The audience knows of only two who live in Villeneuve before 
1940, both of whom moved to the town as adults, a servant of Czechoslovak origin and the director of the school. In perhaps the most dramatic set of episodes in the series, a trainload of Jews being sent to Drancy in July 1942, at the time of the Vel d'Hiv roundup, are stuck in Villeneuve when their train breaks down. While these Jews are largely Central European refugees, the primary story lines concern Jews in Villeneuve who are arrested and confined with them. A Gaullist resister breaks with the leadership of the group in an effort to save a Jewish girl, but only because she is the daughter of a fellow resister. Hortense Larcher, the mayor's wife, changes places with her husband's Jewish mistress, Sarah, and only narrowly escapes deportation; she herself is the mistress of the SS officer Heinrich Müller, whom she had earlier gotten to take care of problems with Sarah's papers. These scenes reveal important facets of Hortense's character, deepening a central element of the drama, but they also challenge the limits of the historical imagination. This prompts a good discussion of the relation of storytelling to the telling of history. Students develop the idea of historical imagination as a means to deepen their understanding of the past by taking them from what happened and why to the questions of what was possible and impossible in a particular historical situation and why. ${ }^{13}$ Having entered an imagined world in A French Village, students have some of their most sustained debates about imagining the past as a means of accessing what historians may not be able to see in the past as it existed and why.

No place is the showrunners' effort to make viewers rethink their understanding of the past clearer than in episodes devoted to Villeneuve after the Germans depart. A couple of officials of the Third Republic had initially retained their positions after the arrival of the Germans, but then went rogue and entered the national resistance movement. They return to Villeneuve at liberation in positions of importance in the new regime. These officials immediately begin cutting deals to allow them to keep their power while preserving a veneer of the political and social justice for which the resistance fought. The town hosts a party to celebrate liberation, but it takes place in the midst of a trial of Milice members, who are held in a pen in the center of town during the festivities. Trial deliberations are themselves confined by the need to balance the new government's demand for severity with the American desire to see a trial that appears fair. The unity of the resistance is lost, and some resisters take it upon themselves to render justice, culminating in the lynching of a number of Milice members. An angry crowd condemns Hortense Larcher for horizontal collaboration and shaves her head. ${ }^{14}$

The trial of Daniel Larcher is presented in such a way as to make the audience rethink their understanding of collaboration. The series audience sees his collaboration as involving efforts to defend the population, but in the trial these acts become apparently damning accusations against him. Events are remembered in a new context. Flashbacks to previous episodes of the show become the evidence that refutes, for the viewers, a witness's adamant denial that French gendarmes separated Jewish children from their parents in Villeneuve, saying only the Germans did this. Like the best microhistories, A French Village works on several levels. ${ }^{15}$ It recognizes that there are different kinds of knowledge about the occupation operating in postwar France. In addition to acts open to interpretation as collaboration in trials and by crowds, the world of illicit behaviors the occupation nurtured and required created suspicions and hidden records that individuals use after liberation to get their way with others who need what happened in the occupation to stay in the occupation.

Thinking as showrunners as well as historians, students confront the question of how one ends a series and debate the choices made in A French Village, in which the fates of the major figures are a function of the legacies of the occupation and how these are given meaning in new contexts. French participation in the Holocaust was the unspoken of the first decades after the war. The Holocaust comes up in several ways in the final episodes of the series. When Hortense Larcher recounts to her husband that an Auschwitz survivor came to tell him that his mistress Sarah died in the camp, he does not believe his wife, who has been exhibiting paranoia since she

\footnotetext{
${ }^{13}$ Vivienne Little, "What is Historical Imagination?," Teaching History 36 (June 1983): 27-32.

${ }^{14}$ In what feels like an editorial comment by the scriptwriters, one of the most-hot headed of the resisters stands back from the assault, saying that fascists during the Spanish Civil War had shorn female Republicans.

${ }^{15}$ Sigurður Gylfi Magnússon and István M. Szijártó, What is Microhistory? Theory and Practice (Abingdon-on-Thames: Routledge, 2013).
} 
was publicly humiliated. Although the audience knows Hortense is telling the truth, he has her committed to an asylum, where the patients are treated cruelly, and the food rations are kept at occupation-era levels. It is not a concentration camp, but the showrunners want the audience to know that the end of the camps did not mean the end of inhumanity. ${ }^{16}$

Jean Marchetti is executed, but his love, Rita de Witte, and Ézechiel Cohn, a Jewish refugee in Villeneuve, form a couple and go to Palestine. There they are killed by Arab fighters, who call out Deir Yassin, as they attack. When Ézechiel tells Rita that this is a Palestinian village where Jewish fighters killed women and children, she responds, "We're like them now." Once again, the showrunners are reminding viewers that inhumanity and injustice continued in the lives of survivors of the occupation. However, suggesting a relationship of the Jews in Palestine to the Germans during the war sparks an important discussion among students, who wonder if this works to lessen French responsibility for participation in the Holocaust with an everyone-does-it argument. Three decades after the end of the war, Daniel Larcher arranges for the cultural center in Villeneuve to show his wife Hortense's paintings. Jewish activists attack the exhibit of the SS officer's mistress, and it is closed. Hortense can only say that Jews were not like this in her day.

If the original repressed memory of the occupation was the nature and extent of collaboration with the Germans, in A French Village this takes the form of the life-changing loves of both Hortense and the schoolteacher, Lucienne, for Germans in the occupation forces. After the war, they stay loyal to these loves but cannot speak of them. The showrunners suggest that there are other forms of collaboration than those of the mayors, state officials, and business people that the French still do not fully recognize. It is represented in the series by Lucienne's daughter, Françoise, one of the one hundred thousand children who were born to French women and German fathers during the war. She takes her mother to visit her father's grave but is told neither that he was German nor that he was her father. Students explore the blind spots that personal and collective memory can reinforce in one another.

Although a lie told by the local Communist leader to the authorities creates the opportunity for the party to win the postwar election in Villeneuve, taking power that it holds for decades, it also leads to the death of a striking worker. The postwar history of the Communists is presented as the beginning of the end. The activist Suzanne leaves the party after learning about the leader's dishonesty and becomes a feminist who appears on television decades later supporting a woman's right to choose. Her daughter leaves the party, too, and works in a women's health clinic. Both find fulfillment in feminism, one of the new social movements that takes the place of the party for many activists in the 1970s. Those who remain in the party are lost souls. Max, a Communist resister sent to the Oranienburg concentration camp, had been liberated by Soviet troops and spent seven months in the Soviet Union where he learned of the horrors of Stalinist rule. Yet he cannot leave the party on his return to France; he quotes a Soviet poet: "My house is sick, but it is my house." Gustave, the orphan of a Communist resister executed by the Germans, is stuck in the past, delighting at the opportunity in 1975 to hear a comrade sing Stalinist ditties. American students bring a post-Cold War indifference to interpreting Communists in the series. If many French would put the Communists in a "gray zone," the students recognize that their sympathy for Communist characters as individuals can never extend to their commitment to the party.

\section{Conclusions}

What do students take from a semester talking and writing about a television series? They confront directly the viewers' sense that they "know" this history because they have seen it and have, in a sense, lived through it. They better understand what they see in a television drama series by thinking about the many decisions about history as well as aesthetics that showrunners make. Audiences have always sought the "you were there" experience in film; this course leads students to recognize that to understand that feeling, they need to imagine they were

\footnotetext{
${ }^{16}$ Jean-Pierre Azéma wrote a report of the treatment of patients in psychiatric hospitals during the war at the request of the French state when it was considering a memorial to mental patients and their horrific experiences during the Occupation, October 2015. See https://solidarites-sante.gouv.fr/IMG/pdf/rapport-azema_20102015.pdf
} 
there at the meetings to review scripts and to watch rushes, and to decide what "there" they want the audience to experience and how to achieve it. Students, in turn, are aware that the term "audience" homogenizes groups whose reception of the series differs. In particular, they recognize that male and female students interpret the individuals and events in the series and their place in history differently. One student wrote an exceptional paper on this, using class discussion as her source. The course enables students to see that the dramatic presentation of history is not simply a question of accuracy and verisimilitude. By engaging constantly with difficult decisions showrunners necessarily make, they come to see the ways story could be used to bring history to a wider public, while in turn exploring their own understandings of the political, cultural and moral life in occupied France.

As with all documents, students need to recognize when and why a series was created and, in turn, the effects of the environment in which they interpret it. Their historically-situated response to the Communists provides one example. Their reflection on Marie Germaine, the character they found most sympathetic, provides another. What did they take from their twenty-first century appreciation of her? She appears to enjoy sex as more or less an equal with her partners, whereas being dominated is appealing to other major female figures like Hortense (by Heinrich Müller) and Jeannine (by Philippe Chassagne). When Marie realizes that a woman has an unwanted pregnancy, she arranges an abortion, in the clearest act of sisterhood and evidence of a prewar underground in the series. Marie, in fact, seems to be a twenty-first century character living in the 1940s. She is the leader of the Gaullist resistance in Villeneuve. Men compete among themselves and though they would normally unite in keeping women in their place, they could also unite under an exceptional woman because she was exceptional and because she was not a dominant male. She feels like a present-day heroine in her navigation of personal relationships and her rise within the new public sphere of the resistance. Her story resonates with a contemporary form of resistance-feminism. She makes the historically-situated story of resistance meaningful to an audience today. Marie dies a martyr not to the resistance, but to feminism, by antagonizing Marchetti with a challenge to his virility. Did the showrunners, students asked, want to finish her off so as not to leave the audience disappointed that there was no place for a Superwoman in France in the years following liberation?

The class closed with students exploring other historical events whose ambiguities and interpretive debates that they believed dramatic recreation could bring to the public. The public changes, so success itself is historically situated. Some had seen the television series Holocaust (1978), directed by Gerald Green. They appreciated its importance in revealing a repressed history when it was first screened, but now saw it as wooden and dated, lacking an engagement with the complexities of history. ${ }^{17}$ However, there are other possibilities. Inspired by $A$ French Village, Brian de Palma is working with Frédéric Krivine on Newton 1861, a television series set in a town in Kentucky during the Civil War. ${ }^{18}$ We look forward to being challenged and to challenging the result.

\footnotetext{
${ }^{17}$ A French Village is not the first series mobilized to explain the wartime world to the French. Networks in France did not initially express interest in broadcasting Holocaust. However, in response to the emergence of a current of Holocaust denial, a public television chain screened the series in 1979. Nadine Fresco, Fabrication d'un antisémite (Paris: Seuil, 1999$), 53$.

${ }^{18}$ Pierre Langlois, "Exclusif: Brian De Palma prépare une adaptation américaine de la série Un Village français", Télérama, April 9, 2019. https://www.telerama.fr/series-tv/exclusif-brian-de-palma-prepare-une-adaptation-americaine-de-la-serie-un-villagefrancais,n6207199.php
} 